\title{
Vértices: trajetória e desafios de uma revista científica do Instituto Federal Fluminense
}

\author{
Inez Barcellos de Andrade e Edson Carlos Nascimento
}

\section{INTRODUÇÃO}

O objetivo deste trabalho é descrever a trajetória da revista Vértices, destacando suas especificidades enquanto publicação científica da Essentia Editora pertencente a uma Instituição de Ensino Superior (IES) da Rede Federal de Educação Profissional, Científica e Tecnológica, o Instituto Federal em Educação, Ciência e Tecnologia Fluminense (IFF), e os desafios concernentes a essa realidade.

\section{TRAJETÓRIA}

Lançada em 1997 como publicação quadrimestral de divulgação técnico-cultural da então Escola Técnica Federal de Campos (ETFC) para ser um ponto de convergência de desenvolvimento da "Federal" e da região, representando diferentes ideias, concepções, abordagens, numa vontade única de disseminar conhecimento e cultura.

Em 22 anos, muitas mudanças na instituição, no contexto do ensino tecnológico e da educação:

- De ETFC para CEFET em 1999;

- De CEFET para IFF em 2009.

A revista Vértices acompanha essas mudanças tanto na sua composição e proposta quanto na sua abrangência, estrutura, aspecto e formato com ações que incluíram:

- Implementação em 2009 do sistema OJS (antigo SEER) http://www.essentiaeditora.iff.edu.br/index.php/vertices/about, com foco a proposta de ser uma publicação periódica técnicocientífica de artigos originais sobre temas relevantes nas diversas áreas do conhecimento humano, em âmbito nacional ou internacional;

- Indexação em diferentes bases de dados e repositórios tais como Latindex, Diadorim, RCCAP, BBE, DOAJ, Sumarios.org, Livre, LatinRev. Na avaliação do Qualis CAPES (2013-2016) destaca-se a classificação B2 para Educação e Serviço Social, entre outras.

- Publicação de 57 fascículos, em 21 volumes, 504 artigos, sendo 465 originais e 39 de revisão.

- Aumento da participação de autores externos, diminuindo a endogenia e alcance da pontualidade e periodicidade propostas.

- Formação de um Conselho Editorial Especializado de com abrangência nacional, representando as diferentes áreas do conhecimento, além da nomeação de dois editores (assistente e associado).

- Filiação e participação dos editores da revista Vértices nos eventos da ABEC em busca de profissionalização.

Dentre os quesitos relevantes para a qualidade do periódico estão: a publicação de bons artigos, corpo editorial reconhecido, periodicidade regular, abrangência do acesso aos artigos, os quais possibilitam a inclusão em bases indexadas, ampliando a sua visibilidade.

\section{DESAFIOS ATUAIS}

- Manter o objetivo inicial: "contribuir para a disseminação do conhecimento, além do desenvolvimento local e regional";

- Seguir as diferentes recomendações das áreas;

- Ações para captação de artigos originais e de qualidade;

- Obter o retorno das avaliações realizadas pelos pareceristas;

- Manter o apoio e capacitar a equipe técnica;

- Indexar em novas bases de dados.

\section{CONSIDERAÇÕES FINAIS}

Em meio aos desafios e dificuldades que a ciência brasileira vem enfrentando, a revista Vértices por meio dos seus editores e equipe editorial, com apoio de seus parceiros (autores, leitores, avaliadores) reafirma que permanece o seu compromisso em buscar caminhos para democratização do conhecimento e elevação dos níveis da produção intelectual e cultural em nosso país.

\section{REFERÊNCIAS}

BOMFÁ, C. R. Z. Modelo de gestão de periódicos científicos eletrônicos com foco na promoção da visibilidade. Florianópolis, 2009. 238f. Tese (Doutorado em Engenharia de Produção) - Programa de Pós-Graduação em Engenharia de Produção, Universidade Federal de Santa Catarina. 